\title{
Employees' Commitment Influence on Quality of Management Methods - Empirical Research Based on Different Business Contexts
}

\author{
Katarzyna TWOREK \\ Wroclaw University of Science and Technology, Wroclaw, Poland \\ Katarzyna.tworekepwr.edu.pl
}

\begin{abstract}
The paper concerns the role of employees' commitment in increasing the quality of management methods used in organizations. The first part of the paper concerns the theoretical background for formulation of research hypotheses concerning this relation occurrence in different business contexts (developing and developed economy). The second part of the paper presents the results of empirical research conducted among more than 1000 organizations from Poland (as an example of developing economy) and Switzerland (as the example of developed economy). The obtained results confirm the existence of assumed relations.
\end{abstract}

Keywords: Management, Employees' Commitment, Management Methods Quality, Empirical Research.

\section{Introduction}

Employees' commitment is a subject that appeared in the literature in the 1990s under the terms "high commitment", "high involvement", "high performance" [20] and after a while it even evolved into the method of employees' commitment management. It is understood as "employees' faithfulness to the organization, the willingness to exert effort on behalf of the organization, the degree of goal and value between the employee and the organization, and the employee's desire to remain hired by the organization" [15]. In recent years, the literature indicates the growing importance of employees' commitment in the organization as a factor affecting the organization's ability to build competitive advantage and increase organizational performance [6]. However, it seems that above all else, employees' commitment has the capacity to influence the management methods quality, which is considered as one of drivers of performance in contemporary organizations $[3,10]$. Moreover, as the management methods use and quality is significantly differing depending on business context and they are considered to be an important factor supporting the improvement of organizations operating in developing economies during their transition to developed economies (even though their availability and skills needed for proper use are weaker), it seems that the business context might be an important moderator of this 
relation. The literature coverage of the role of employees in fostering and sustaining management methods quality is very weak and conclusions concerning this relation are non-existent. Therefore, the main aim of the article is to analyze and verify the potential influence of employees' commitment on quality of management methods implemented in organization with regard to different business contexts.

\section{Management Methods in Organization}

The management of organization is connected to five basic notions (defined by [10, 17]): concept, methodology, methods, techniques and management solutions. Concept are considered to be a comprehensive, developed and defined basis for consideration of any idea. Methodology is understood as the entity or closely related collection of methods, rules and disciplinary postulates. Methods are defined as goal- and problem- ordered types of procedures, which are especially regular and systemic ways of setting and realizing the given goal. Techniques are the manner in which technical details are treated. Corresponding management solutions are understood as the way for realization of management ideas.

Management methods quality is a notion not very well analyzed in the literature $[3,12]$. The notion of quality is defined by ISO 9000 as the "degree to which a set of inherent characteristics fulfils requirement". Therefore, the quality is the degree to which set of features or characteristics of a product or service influences its ability to satisfy stated or implied needs. It may be then assumed that a product or a service has good quality when it complies with the requirements, which are specified by different stakeholders. Based on that, management method quality can be defined as a degree to which management methods fulfill the requirements specified by the organization, i.e. its implementation and use are allowing organization to obtain a desired level of results [17].

\section{Employees' Commitment Role in Improving Management Methods Quality}

The relation between management methods quality and employees' commitment is highly dependent on the type of management method. It is especially true for the Human Resources Management (HRM) methods, which directly refer to a strategy designed to acquire, develop, manage, motivate, and gain the commitment of employees as key resources to the organization [2], will be much more closely related to employees' commitment than other management methods. However, what is true for all management methods, employees' commitment ensures that all practices, including management methods implemented in organization, conform to quality requirements and moreover, are followed by all employees from the organization [7, 14]. Therefore, it seems that there is a potential for the relation between employees' commitment and management methods quality [17]. The interest in examining these relations began at the turn of the century, after the industrial revolution caused 
managers from all types of industries to look for a new definition of work, role of employee and different ways to increase organizational performance [1,5]. Van der Wiele et al. [19] analyzed acceptance of philosophy of TQM and stated that it has significant human resources implications and employees' commitment is one of the affected aspects. The majority of authors suggest that employees' commitment is sort of prerequisite for enhancing quality of management methods in organization. First of all, because of the fact that according to studies closely related to employees' commitment [1], connected with OCB [11], motivation [8, 18], and social exchange [9] - the higher is their commitment, the better is the quality of solutions, which are available for the employees, as they are able to see that they have all they need to perform their tasks efficiently and only their commitment and approach to their job may stop them from achieving goals, which fosters the increase of that commitment and influences quality of solutions, which is dependent on their proper (and committed) use. Management methods are one of the most important sources of solutions available for employees [4]. Second of all, and more importantly, the quality of management methods is highly dependent on their ability to fulfill the organizations' requirements [17]. Hence, the high level of employees' commitment is a prerequisite enabling employees to use available management methods to fulfill those needs. Without that, the simple fact of those methods' availability will not be able to generate any benefits for the organization. Hence, it can be assumed that there is a possibility that employees' commitment influences quality of management methods. Therefore, following hypotheses are formulated:

H1: Both in organizations operating in Poland and Switzerland, there is a positive relation between management methods quality and employees' commitment.

H2: Employees' commitment influences the quality of management methods used in organization.

Moreover, there is another factor which should be considered in case of this relation business context. The business context significantly influences the organizations' access to business solutions, which differs in case of their complexity, maturity and availability. Management methods can be considered as one of those solutions. Therefore, it may be assumed that in more developed economy, where the availability of more mature and complex management methods is higher and they are used for a significantly longer period of time, the role of their determinants will be more significant. Moreover, management methods are considered to be an important factor, which supports the improvement of organizations operating in developing economies. They are prone to reduce the gap between developing and developed economies [10, $13,16]$. Therefore, it would be easier to achieve high management methods quality im more developed economies and averagely higher levels of employees' commitment will more significantly influence it. Therefore, the following hypothesis can be formulated: 
H3: In organizations operating in Switzerland, the influence of employees' commitment on quality of management methods implementation in organization is stronger than in organizations operating in Poland.

An overview of the proposed hypotheses is presented in Figure 1.

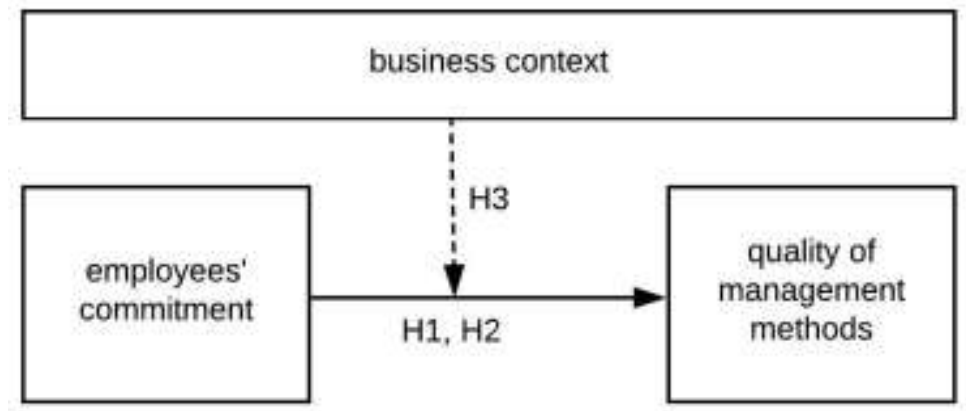

Fig. 1. An overview of research hypotheses.

\section{Empirical Research Overview}

In order to verify the proposed hypotheses and identify the level of all variables needed to achieve this aim in two business contexts, the survey was conducted and it is presented in [17]. The main survey was preceded by the pilot one conducted at the beginning of 2018 among the group of 50 organizations. It identified the issues concerning ambiguity of several questions. The ambiguous questions were rewritten in order to obtain more informed response from the organizations participating in main survey and two questions were omitted because they generated unreliable responses. The main research was conducted as a part of a research project "The IT reliability influence on the quality of management methods and techniques", no. 2017/01/X/HS4/01967 financed from the funds of the National Science Center in Poland. The main survey was conducted in March 2018, among organizations located in Poland and Switzerland, which was the only condition limiting the sample (organizations were surveyed regardless of size, industry or type of business etc.), using online survey service: SurveyMonkey. Respondents panels provided by the SurveyMonkey were used as the sampling technique. Only one survey was carried out anonymously in one organization, and it was completed by employees who have a broad view of the entire organization.

\subsection{Research Sample Overview}

The research sample contains the organizations, chosen randomly from a purchased respondent's panel, operating in Poland and Switzerland. 558 valid responses were collected from Poland and 564 valid responses were collected from Switzerland [17]. It is a very large sample for this kind of study and can be a basis for overall 
conclusions concerning the given topic. Sample characteristics are presented in Table 1 and clearly show that the sample is covering organizations of all sizes and all types. The selection of organizations from two countries is intentional and is aimed at including into the sample organizations assessing their employees' commitment and management methods quality as low (below 3 , what is true for sample from Poland) and as high (above 3, what is true for sample from Switzerland). Moreover, as one of the aims of the publication is the analysis of differences between developing and developed economy, the selection of research sample containing organization operating in both of them was crucial.

Table 1. Research sample characteristics from Poland.

\begin{tabular}{lcc}
\hline Organization size & Poland & Switzerland \\
\hline Micro (below 10 people) & 107 & 114 \\
Small (11-50 people) & 140 & 134 \\
Medium (51-250 people) & 134 & 114 \\
Large (above 250 people) & 177 & 202 \\
Total & 558 & 564 \\
\hline
\end{tabular}

\subsection{Variables Overview}

Three variables were identified in order to verify the formulated hypothesis.

Management methods quality will be measured with results obtained due to implementation of all management methods implemented in organization. 18 results were identified and their change caused by implementation of each management method (and all management methods in organization) was measured on a Likert scale (from very positive influence to very negative influence with the middle point: no influence). Based on the assessment of every item (one item = one result), four key variables were defined [17]: results related to efficiency, results related to employees, results related to product and results related to innovativeness. An overview of the variables' development is presented in Table 2.

Table 2. Overview of variable: management methods quality.

\begin{tabular}{cl}
\hline \multicolumn{1}{c}{ Group } & Items \\
\hline & $\begin{array}{l}\text { Adaptation of the organization to changes taking place } \\
\text { in the environment }\end{array}$ \\
\cline { 2 - 2 } $\begin{array}{c}\text { Results related } \\
\text { to efficiency }\end{array}$ & $\begin{array}{l}\text { Increase of the chances for the long-term existence of } \\
\text { the organization }\end{array}$ \\
\cline { 2 - 2 } & $\begin{array}{l}\text { Overall increase in the efficiency of the organization's } \\
\text { management }\end{array}$ \\
\hline & More effective achievement of the organization's goals \\
\hline
\end{tabular}




\begin{tabular}{|c|c|}
\hline & Shortening of the decision-making time \\
\hline \multirow{4}{*}{$\begin{array}{l}\text { Results related } \\
\text { to employees }\end{array}$} & Better flow of information inside the organization \\
\hline & Increase of satisfaction and increase of employee morale \\
\hline & Increase in employee involvement in achieving results \\
\hline & Improvement of the competence of employees \\
\hline \multirow{4}{*}{$\begin{array}{l}\text { Results related } \\
\text { to product }\end{array}$} & $\begin{array}{l}\text { General improvement of the organization's financial } \\
\text { results }\end{array}$ \\
\hline & $\begin{array}{l}\text { More effective and more rational management of the } \\
\text { organization's resources }\end{array}$ \\
\hline & Increase in the quality of products \\
\hline & Improvement of the timeliness of production orders \\
\hline \multirow{4}{*}{$\begin{array}{l}\text { Results related } \\
\text { to } \\
\text { innovativeness }\end{array}$} & Increase in the number of changes in products / services \\
\hline & Increase in the number of changes in business processes \\
\hline & Increase in the number of organizational changes \\
\hline & Increase in the number of marketing changes \\
\hline
\end{tabular}

Employees' commitment will be measured based on eight commitment building elements, based on methodology developed by Mone and London (2009) and Mone et al. (2018) presented in Table 3. The items were phrased in form of statements to be evaluated on a Likert scale (from I strongly agree to I strongly disagree with a middle point: I do not have an opinion) [17]. One key variable was defined: employees' commitment.

Table 3. Table captions should be placed above the tables.

\begin{tabular}{|c|c|}
\hline Group & Items \\
\hline \multirow{8}{*}{$\begin{array}{l}\text { Employees' } \\
\text { commitment }\end{array}$} & $\begin{array}{l}\text { employees are motivated to improve their productivity } \\
\text { and find better ways to do their job, }\end{array}$ \\
\hline & $\begin{array}{l}\text { communication on the part of the organization's } \\
\text { management helps employees to understand the } \\
\text { organization's strategies, missions and goals, }\end{array}$ \\
\hline & $\begin{array}{l}\text { employees feel that they have enough resources to do } \\
\text { their job effectively, }\end{array}$ \\
\hline & $\begin{array}{l}\text { employees feel that the management of the organization } \\
\text { thinks about their good, }\end{array}$ \\
\hline & $\begin{array}{l}\text { employees are satisfied with the possibilities of } \\
\text { promotions and personal development, }\end{array}$ \\
\hline & $\begin{array}{l}\text { employees recognize that not only payment, but also } \\
\text { additional benefits and work atmosphere are benefits } \\
\text { from employment, }\end{array}$ \\
\hline & $\begin{array}{l}\text { employees have confidence in the management of the } \\
\text { organization, }\end{array}$ \\
\hline & $\begin{array}{l}\text { employees believe that they receive enough feedback } \\
\text { from their supervisors to improve their efficiency on this } \\
\text { basis. }\end{array}$ \\
\hline
\end{tabular}




\subsection{Research Results}

In order to verify the proposed set of hypotheses, the U Mann - Whitney, correlation and regression analysis was performed. First, the differences between averages values of variables obtained from samples from Poland and Switzerland were verified and the results are presented in table 4 .

Table 4. Results obtained due to implementation of management methods and employees' commitment in organizations from Poland and Switzerland.

\begin{tabular}{|c|c|c|c|c|c|c|c|c|}
\hline \multirow[b]{3}{*}{$\begin{array}{l}\text { Results related } \\
\text { to efficiency }\end{array}$} & \multicolumn{3}{|c|}{ Poland $(n=558)$} & \multicolumn{3}{|c|}{ Switzerland $(n=564)$} & \multicolumn{2}{|c|}{$\begin{array}{l}\text { Test U Mann - } \\
\text { Whitney }\end{array}$} \\
\hline & M & SD & $\mathrm{MD}$ & M & SD & MD & Z & $\mathrm{p}$ \\
\hline & 2.19 & 0.65 & 2.14 & 3.54 & 1.01 & 3.71 & -18.556 & $<0.01$ \\
\hline $\begin{array}{l}\text { Results related } \\
\text { to employees }\end{array}$ & 2.15 & 0.75 & 2.00 & 3.58 & 1.10 & 4.00 & -17.984 & $<0.01$ \\
\hline $\begin{array}{l}\text { Results related } \\
\text { to product }\end{array}$ & 2.17 & 0.72 & 2.25 & 3.52 & 1.05 & 3.50 & -17.981 & $<0.01$ \\
\hline $\begin{array}{l}\text { Results related } \\
\text { to } \\
\text { innovativeness }\end{array}$ & 2.27 & 0.72 & 2.25 & 3.56 & 1.05 & 3.50 & -17.536 & $<0.01$ \\
\hline $\begin{array}{l}\text { Employees' } \\
\text { commitment }\end{array}$ & 2.66 & 0.91 & 2.50 & 3.52 & 1.11 & 3.50 & -13.472 & $<0.01$ \\
\hline
\end{tabular}

The obtained results allowed to verify that Poland and Switzerland are indeed various business contexts and quality of management methods (in case of all groups of results) and employees commitment is evaluated positively in Switzerland ( $\mathrm{M}>$ $3.0)$ and negatively in Poland $(M<3.0)$. Next, the correlation analysis was performed and the results are presented in table 5 .

Table 5. Correlation analysis results

\begin{tabular}{lcc}
\hline & $\begin{array}{c}\text { Employees' } \\
\text { commitment } \\
\text { (Poland) }\end{array}$ & $\begin{array}{c}\text { Employees' } \\
\text { commitment } \\
\text { (Switzerland) }\end{array}$ \\
\hline Results related to efficiency & $\mathrm{r}=0.177 ; \mathrm{p}<0.01$ & $\mathrm{r}=0.632 ; \mathrm{p}<0.01$ \\
Results related to employees & $\mathrm{r}=0.177 ; \mathrm{p}<0.01$ & $\mathrm{r}=0.653 ; \mathrm{p}<0.01$ \\
Results related to product & $\mathrm{r}=0.166 ; \mathrm{p}<0.01$ & $\mathrm{r}=0.611 ; \mathrm{p}<0.01$ \\
Results related to innovativeness & $\mathrm{r}=0.157 ; \mathrm{p}<0.01$ & $\mathrm{r}=0.557 ; \mathrm{p}<0.01$ \\
Results (overall) & $\mathrm{r}=0.173 ; \mathrm{p}<0.01$ & $\mathrm{r}=0.599 ; \mathrm{p}<0.01$ \\
\hline
\end{tabular}

The obtained results confirm that indeed there is a statistically significant relation between management methods quality and employees' commitment, which allows for 
acceptance of hypothesis H1. Moreover, the correlation is weak in case of sample from Poland and strong in case of sample from Switzerland. It furthermore confirms a huge difference between those business contexts. Next, the regression analysis with moderator was performed in order to verify the hypotheses $\mathrm{H} 2$ and $\mathrm{H} 3$. The results of the analysis are presented in table 6 .

Table 6. Regression analysis results

\begin{tabular}{|c|c|c|c|c|c|c|}
\hline Model description & $\begin{array}{c}\text { Model } F \\
\text { stats }\end{array}$ & $R^{2}$ & $\begin{array}{c}\text { Delta } \\
R^{2} \\
\end{array}$ & $\begin{array}{c}\text { Moderator } \\
\text { coeff. }\end{array}$ & t Stat & $\begin{array}{c}P \\
\text { Value } \\
\end{array}$ \\
\hline $\begin{array}{l}\text { Employees' } \\
\text { commitment, }\end{array}$ & & & & 0.9577 & 7.7618 & 0.001 \\
\hline Business context, & & & & 2.6384 & 13.935 & 0.001 \\
\hline Moderator & & & & -0.5227 & -7.2973 & 0.001 \\
\hline $\begin{array}{l}\text { dependent v.: } \\
\text { results (overall) }\end{array}$ & 279.038 & 0.417 & 0.036 & & & \\
\hline
\end{tabular}

The obtained results allow to verify the cause-effect relation between employees' commitment and management methods quality due to obtained statistically significant and well fitted regression model (in which employees' commitment is a statistically significant independent variable), which is a basis for accepting H2 hypothesis. Moreover, that business context is a statistically significant moderator of the relation between employees' commitment and management methods quality $(p<0.001)$, which allows to accept the hypothesis $\mathrm{H} 3$.

\subsection{Discussion}

The performed empirical research is a basis for positive verification of employees' commitment influence on management methods quality, which occurs in case of both analyzed business contexts. However, in case of polish organizations (from less developed economy), the strength of the analyzed relation is much lower than in case of swiss organizations. It confirms the assumption that the analyzed relation is much more significant in more developed economy. In the light of U Mann - Whitney statistical test it can be furthermore confirmed that assumed reasons for that fact were correct - employees' commitment and quality of implemented management methods is generally assessed much higher in organizations from more developed economy. Moreover, the analysis confirms that business context is a significant moderator of the confirmed cause-effect relation between employees' commitment and management methods quality. 


\section{Conclusions}

The main aim of the article was the analysis and verification of potential influence of employees' commitment on quality of management methods implemented in organization with regard to different business contexts. The empirical research performed among more than 1000 organizations from Poland and Switzerland allowed to verify that employees' commitment is statistically significantly influencing quality of management methods used in organization. Moreover, business context is significantly moderating that relation. The level of economy development is strengthening the employees' commitment influence on management methods quality, especially in the aspect of results connected with employees, which is consistent with assumptions.

The performed research has some limitations - only two countries were selected as the examples of business contexts. It requires further verification. Moreover, the quality of all management methods used in organization (in general) was analyzed and it seems that there might be significant differences between different management methods. It seems to be a valid topic for further research.

Acknowledgements. The paper was created as a result of the research project no. 2017/01/X/HS4/01967 financed from the funds of the National Science Center.

\section{References}

1. Adzeh, K. J.: Assessing the influence of organizational commitment on employee perceptions of superior customer value creation (Order No. 3554829). Available from ABI/INFORM Collection; ProQuest Central; ProQuest Dissertations \& Theses A\&I; ProQuest Dissertations \& Theses Global. (1317633519) (2013).

2. Ahmed, S.: The emerging measure of effectiveness for human resource management: An exploratory study with performance appraisal. Journal of management development 18(6), 543-556 (1999).

3. Bieńkowska, A.: Analiza rozwiązań i wzorce controlling w organizacji, Oficyna Wydawnicza Politechniki Wrocławskiej (PWr), Wrocław (2015).

4. Bieńkowska, A., Zgrzywa-Ziemak, A.: Współczesne metody zarządzania w przedsiębiorstwach funkcjonujących w Polsce - identyfikacja stanu istniejącego. In: Hopej, M., Kral, Z. (eds.) Współczesne metody zarządzania w teorii i praktyce, Oficyna Wydawnicza PWr, Wrocław (2011).

5. Chalofsky, N., \& Krishna, V.: Meaningfulness, commitment, and engagement: The intersection of a deeper level of intrinsic motivation. Advances in Developing Human Resources 11(2), 189-203 (2009).

6. Kompaso, S. M., \& Sridevi, M. S.: Employee engagement: The key to improving performance. International journal of business and management 5(12), 89 (2010).

7. Mendes, L.: Employees involvement and quality improvement in manufacturing small and medium enterprise (SME): A comparative analysis. African Journal of Business Management 6(23), 6980-6996 (2012). 
8. Milne, P. :Motivation, incentives and organisational culture. Journal of Knowledge Management 11(6), 28-38 (2007). DOI:10.1108/13673270710832145.

9. Mitchell, M. S., \& Cropanzano, R.: Social exchange theory: An interdisciplinary review. Journal of Management 31(6), 874-900 (2005). DOI:10.1177/0149206305279602

10. Nedelko, Z., \& Potočan, V.: Management practices utilization in organizations-A comparison between catching-up and well-developed economies. Management: journal of contemporary management issues $21,1-20$ (2016).

11. Organ, D. W.: Organizational citizenship behavior: Its construct clean-up time. Human Performance 10(2), 85-97 (1997). DOI:10.1207/s15327043hup10022

12. Potocan, V., Dabic, M.: Management tools in business environment. Maribor, Slovenia: Faculty of Economics and Business (2012).

13. Potocan, V., \& Mulej, M.: How to improve innovativeness of small and medium enterprises. Management 14(1), 1-20 (2009).

14. Pun, K. F., Chin, K. S., \& Gill, R.: Determinants of employee involvement practices in manufacturing enterprises. Total Quality Management, 12(1), 95-109.anufacturing Enterprises. Total. Qual. Manage 12(1), 95-109 (2001).

15. Ramdhani, A., Ramdhani, M. A., \& Ainissyifa, H.: Conceptual Framework of Corporate Culture Influenced on Employees Commitment to Organization. International Business Management 11(3), 826-830 (2017).

16. Sapkauskiene, A., \& Leitoniene, S.: The concept of time-based competition in the context of management theory. Engineering Economics 21(2), 205-213 (2010).

17. Tworek, K.: IT - Business Alignment. Springer-Verlag, In press (2019).

18. Udechukwu, I. I.: Correctional officer turnover: Of Maslow's needs hierarchy and Herzberg's motivation theory. Public Personnel Management 38(2), 69-82 (2009).

19. Van der Wiele A, Dale BG, Williams A.: ISO 9000 Series Registration to Total Quality Management: The Transformation Journey. Int. J. Qua.l Sci. 2(4), 236-252 (1997).

20. Wood, S., \& De Menezes, L.: High commitment management in the UK: Evidence from the workplace industrial relations survey, and employers' manpower and skills practices survey. Human Relations 51(4), 485-515 (1998). 